\title{
Becoming Austrian: Women, the State, and Citizenship in World War I
}

\author{
Maureen Healy
}

I

$\mathrm{N}$ late July 1914, upon partial mobilization of the Austro-Hungarian army, an urgent appeal to "Austria's women" circulated widely in the Viennese press. It urged women to "perform service in the time of war" and reminded them that in this moment of state peril, women had to suppress their "differences" and display the "strongest solidarity" among themselves. "Women's unity, women's energy, and women's work" would be crucial for the survival of Austria. 'The notice was published by one of the women's groups in what would become the Frauenhilfsaktion Wien, an umbrella organization founded in early August, comprising the major women's groups in the city. Together with similar subsequent appeals to duty, service, sacrifice, and an inner bond uniting all women, the notice marked the beginning of World War I as a potential turning point in women's relationships with each other and with the state. Across the political spectrum, noble, bourgeois, and working-class women, Christian and Jewish, German-speaking, and others, were asked to put aside their differences and perform war service as "Austria's women."

The term "Austria's women" offers an opening for the study of women's place in late imperial politics. It contains a number of assumptions, contradictions, and possibilities about women's potential solidarity (sisterhood) and their relation to Austria (citizenship). Dissecting the term "Austria's women" allows us to see that contemporary beliefs about women's nature licensed but limited their place in the polity. Although women in postwar Austria and other Habsburg successor states became politically enfranchised at war's end, they did not become citizens overnight. Their citizenship was a process of becoming that began in the prewar period and intensified during the war as women forged new links with the state. In her study of American women, historian Nancy Cott has proposed that citizenship is not an absolute status, it is "not a definitive either/or proposition-you are or you are not-but a compromisable one."'

1. Reprinted in Helene Granitsch, Kriegsdienstleistung der Frauen (Vienna, 1915), 8.

2. Nancy F. Cott, "Marriage and Women's Citizenship in the United States, 1830-1934," American Historical Review 103, no. 5 (1998): 1440-74, 1442.

Central European History, vol. 35, no. 1, 1-35 
Her suggestion that citizenship is to be understood as a spectrum that ranges from the nominal (residence) to the participatory (political rights) is useful in the Austrian context. Although voting rights marked an important change in women's position within Austria, suffrage is just one of several ways of approaching women's citizenship. Equally important are the familial, social, and administrative components of Austrianness that came into play.

What did it mean to be Austrian in 1914? For most inhabitants of the Habsburg lands in the prewar period, one's relation to the state (citizenship) was a far less important category than one's relation to the province and town (domicile) within the empire where one had the right to live, work, and draw on social services. ${ }^{3}$ Although some rights and services extended to all Austrians (allowing people mobility within the state), one's domicile was a more commonly cited attribute of legal identity; in administrative files from the period, for example, a person was described in shorthand by name, date of birth, religion, marital status, and Zuständigkeit, one's proper local jurisdiction. Yet, in wartime, state citizenship became an increasingly important category. This was due to the growing centrality of the state in public discourse; everyday matters such as work, food, leisure, and mourning became matters of state. In January 1919 , a socialist magazine wrote, "In its reality, the war made clear what the state means nowadays for the life of every single person and every family." The fact that there is virtually no historical scholarship on women's citizenship in the Habsburg lands suggests that figuring out how women fit into our understanding of late imperial Austria is not an easy task. ${ }^{5}$ There is no obvious or definitive set of texts to consult. Nonetheless, the upheavals of war provide a few openings that shed light on women's evolving relation to the state. Women entered the war as incipient citizens, dependents of male family members who represented them politically. Five years later, they emerged from war as more formal citizens whose relationship to the state was licensed but limited by their familial capacities as mothers, wives, daughters, or sisters.

Austria was a state, not a nation, and this made the project of mobilizing

3. According to the 1910 census - the last before the war-Vienna had a population of 2,004,939. Of these, 1,816,102 (91 percent) had domicile (Heimatberechtignig) in Vienna itself or in another part of Austria. Legally, we can consider this group citizens of Austria. because in order to possess rights of domicile, one needed to be a citizen (Staatsbirger). See law of 3 December 1863 , $\$ 2$ "Nur Staatsbürger können das Heimatrecht in einer Gemeinde erwerben." Leo Geller, Allgemeines burgerliches Gesetzbuch sammt einschlagigen Vovellen (Vienna, 1892), 150. Of the remaining population, 148,552 ( 7 percent) had donicile in Hungary or Bosnia-Herzegovina and $4(1), 315$ (2 percent) were citizens of foreign countries. Statistisches Jahrbuch der Stadt Wien (Vienna, 1912), 9(3).

4. Der Sozialdemocrat. Monatsschrift der Organisation Wien (1 January 1919): 3. Cited in Reinhard Sieder, "Behind the Lines: Working-Class Family Life in Wartime Vienna," in The Lpheaval of War: Family, Work and Welfare in Europe, 1914-1918, ed. Richard Wall and Jay Winter (Cambridge, 1988), 132.

5. In her useful essay tracing the evolution of Austrian citizenship since the late eighteenth cen- 
Austria's women for war different from mobilizing German, French, or British women. State and nation allow (or demand) different levels of commitment from individuals; one may be loyal to a state but can only truly belong to a nation. In Germany, France, and Britain, women were mobilized on behalf of the nation, and nation has therefore been the key organizing principle guiding most historical studies of women's mobilization in modern European wars. ${ }^{6}$ Within Austria, there were many nationalities, but it was on behalf of the multinational state that the front and home front populations were expected to labor and sacrifice in war. An exhaustive literature exists on the conflicts between nationalities and state in Austria, but we know very little about women's roles in these conflicts. ${ }^{7}$ We do know that Austrians had struggled since the nineteenth century to articulate a modern Staatsidee - an idea of state - that would emotionally bind citizens/subjects to a multinational state in an age of mass politics. ${ }^{8}$ Wartime mobilization offers an ideal moment for investigating how women figure into the discursive possibilities and limitations of "Austria."

This essay focuses on women who lived in or passed through Vienna during the war. The largest urban center in Habsburg Central Europe, Vienna, was predominantly German-speaking but drew immigrants from around the Habsburg domains. Before the war, Vienna's Christian Social Party had reacted to rapid population growth by attempting to preserve legally the "German character" of Vienna. The 1910 census revealed that Vienna's population of just over two million resembled a Central European mosaic. Only 56 percent of residents had legal domicile (Heimatberechtigung) in Vienna-a category that often indicated where a person was born or had come from. The other 44 percent of residents

tury, Hannelore Burger broaches, but does not systematically address, gendered aspects of this citizenship. Hannelore Burger, "Zum Begriff der österreichischen Staatsbürgerschaft: Vom Josephinischen Gesetzbuch zum Staatsgrundgesetz über die allgemeinen Rechte der Staatsbürger," in Geschichte wnd Rech: Festschrift fur Gerald Stourzh zum 70. Geburtstag, ed. Thomas Angerer et al. (Vienna, 1999), 207-23.

6. See, for example, Susan R. Grayzel, Wonen's Identities at War: Gender, Motherhood, and Politics in Britain and France during the First World War (Chapel Hill, 1999); Elisabeth Domansky, "Militarization and Reproduction in World War I Germany," in Society, Culture and the State in Germany, 1870-1930, ed. Geoff Eley (Ann Arbor, 1996), 427-63; Margaret H. Darrow, "French Volunteer Nursing and the Myth of War Experience in World War I," American Historical Review 101, no. 1 (1996): 80-106.

7. Historians have begun to explore links between national identity and women in the Habsburg lands. See Pieter M. Judson, "The Gendered Politics of German Nationalism in Austria, 1880-1900," in Anstrian Women in the Nineteenth and Twentieth Centuries, ed. David F. Good, Margarete Grandner, and Mary Jo Maynes (Providence, 1996), 1-17; Claire Nolte, "'Every Czech a Sokol!' Feminism and Nationalism in the Czech Sokol Movement," Austrian History Yearbook 24 (1993): 79-100; Katherine David, "Czech Feminists and Nationalism in the Late Habsburg Monarchy: "The First in Austria," Journal of Women's History 3, no. 2 (Fall, 1991): 26-45. For a recent historiographical overview, see Edith Saurer, "Women's History in Austria: An Almost Critical Assessment," Austrian History Yearbook 27 (1996): 261-87.

8. Sec Solomon Wank, "Some Reflections on the Habsburg Empire and Its Legacy in the Nationalities Question," Austrian History Yearbook 28 (1997): 131-46. 
had legal domicile in places other than Vienna, most frequently Lower and Upper Austria, Bohemia, Moravia, Hungary, Galicia, Silesia, and the German Empire. (Domicile did not correspond to language; 94 percent of resident citizens were listed as having German as their "language of common use.") ${ }^{4}$ These domicile figures suggest that Vienna was a city of recent arrivals, people whose families had not been in the city long and who may or may not have intended to settle there permanently. Added to this mix came a host of wartime refugees and transient military personnel of various nationalities. In the fall of 1914, between fifty and seventy thousand Polish and Yiddish-speaking refugees arrived from the Galician front, and refugees evacuated from areas behind the Italian front followed the next year. Thus, while Vienna was not representative of Habsburg Central Europe-no one locale could be-it is a useful site from which to look at the experiences of quite a diverse pool of women.

Who would speak for Austria's women in wartime? The first half of this essay takes up questions of women's collectivity, juxtaposing the aspirations of organized women's groups with the actions of womenfolk (Weiber) and female persons (Frauenspersonen) — as they were designated by police agents - who played a central role in public life in wartime Vienna. Without names and without the structures or organization that would make them immediately recognizable as a political group, the womenfolk forcefully and physically demanded that the state had an obligation to provide food in return for civilian sacrifice. Organized women, however, overlooked this female protest in the streets and offered a program of wartime action based instead on supposedly universal feminine traits of maternalism, love, and selflessness. Yet, if we look beyond their published writings to alternative sources such as police records, court files, and correspondence of (anonymous) women with government officials, subjects appear who are women but who act with little apparent relation to a (lasting) female collective.

Judging from this second body of texts, the woman-centered Austrian Burgfrieden of 1914 was something of a fiction. Everyday life in a city of acute shortage pulled at the inner bond supposedly shared by women; the home front as a domain of sisterly collectivity (Mitschwestern) was more evident in pamphlets than in the streets." A competing picture of Vienna, characterized by acts of betrayal of women by women, personal and political sabotage, and woman on woman violence, existed alongside the Frauenhilfsaktion from war's beginning to end. During the war, then, we have parallel developments in women's politics: a vocal minority (organized women's groups) with press and publishing access, speaking on behalf of women, and a large mass of women (the womenfolk and female persons) speaking and acting in uncoordinated ways on behalf of themselves.

10. Bund österreichischer Frauenvereine, ed., Fratenkriegskalender 1915 (Vienna, 1915), 63. 
Viennese women's failure to unite in practice did not spell the end for their theories of feminine nature. These very theories formed the bedrock of women's evolving citizenship. The second half of the essay investigates four instances during the war in which we can see women's citizenship unfolding. We begin, with legal definitions of citizenship carried over from the prewar period. In cases of marriage to foreigners, we see that women's citizenship was determined by the status of their male family members. With no direct relation to the state as individuals, women were citizens one step removed. In the second instance, state payments to families of soldiers, women's dependent status within the family went public when the state stepped in as a surrogate husband in wartime. Third, we see throughout the war that assumptions about women's nature remained central to contemporaries' assessment of women's legal and political accountability, even in cases where their speech or actions were deemed harmful to the state. Finally, near the end of the war, we see in the experiences of Women's Auxiliary Labor Force volunteers the limits of maternal ideology for women's public engagement. In all of these cases, a woman's familial capacity largely shaped perception of her citizenship and determined where she fell on Cott's spectrum of Austrianness. Thus, as female contact with the state intensified during the war, women's groups were partly vindicated: feminine nature might not lead to solidarity among women, but in the eyes of the state, a woman was all, and nothing but, a woman. Her gender was the primary determinant shaping her Austrianness.

Many of the questions raised here are not unique to Vienna or to Austria. Because women across Europe performed labor in wartime that had previously been categorized as male, and because they were granted full or partial suffrage in many European countries at war's end, historians have rightly pinpointed World War I as a period of dramatic rupture in women's everyday lives and in European gender relations more generally. ${ }^{11}$ Historiographical debate has centered on the lasting consequences of this rupture. One line of inquiry that has generated a rich comparative literature in the past decade asks how this gender rupture of World War I figured in the rise of modern European welfare states. ${ }^{12}$ What many historians writing on "women and the state"

11. A large literature now exists on World War I women and gender. Margaret Higonnet, et al., eds., Behind the Lines: Gender and the Two World Wars (New Haven, 1987); Ute Daniel, The War from Within: German Working-Class Women in the First World War, transl. Margaret Ries (Oxford, 1997); Belinda Davis, Home Fires Burning: Food, Politics and Everyday Life in World War I Berlin (Chapel Hill, 200(0); Susan Kingsley Kent, Making Peace: The Reconstruction of Gender in Interwar Europe (Princeton:, 1993). For Austria, see Christa Hämmerle, " ". . wirf ihnen alles hin und schau, dass du fort kommst': Die Feldpost eines Paares in der Geschlechter(un)ordnung des Ersten Weltkrieges," Historische Anthropologie 6, no. 3 (1998): 431-58.

12. See Seth Koven and Sonya Michel, eds. Mothers of a New World: Maternalist Politics and the Origins of Welfare States (New York, 1993); Susan Pedersen, Family, Dependence and the Origins of the Welfare State in Britain and France, 1914-1945 (Cambridge, 1993); Young-sun Hong, Welfare, 
implicitly mean, however, is women and the nation-state. This slippage might explain why multinational Austria, or the Soviet Union for that matter, have been omitted from these comparative projects. In the latter cases, women's legal citizenship hinged on their relationship to the state rather than their membership in a nation. We learn from the study of Austria's women that determining a person's citizenship was a highly subjective enterprise: in addition to legal considerations, there were equally important emotional and psychological components of state loyalty. Citizenship in this part of Central Europe was a matter of feeling rather than solely a matter of law.

\section{The Frauenhilfsaktion Wien}

When the Frauenhilfsaktion Wien convened for the first time on 13 August 1914, those in attendance stood poised to overcome some of the obstacles that had hindered women's unity in the prewar period. As Harriet Anderson explains, "Ironically it was the war which finally brought together the League [of Austrian Women's Associations], the Social Democrats and the Catholic women's movements, who in the previous twenty years had themselves been fighting a war against each other."'3 Philosophical questions about the role of women in society and the desired shape of society itself, as well as concrete questions of education, employment, suffrage, and marriage reform had divided Viennese women's groups into camps that resembled the party-political camps of their male counterparts. ${ }^{1+}$ In Vienna, political discord-whether of class, national, or religious variety - was sometimes referred to as Parteilichkeit-a partiality, bias, or narrow particularism. Parteiliclikeit was a pejorative term that might be applied to the perceived partisanship of one's opponent; its opposite was the nonpartisan, transcendent, common good. When war broke out, state officials and representatives of many organized interest groups, including women, issued exhortations to unity. "[A]lmost overnight," according to the Frauenhilfsaktion Wien, war had mandated that women suspend their Parteilichkeiten and serve an Austria ringed by enemies. War, they believed, accomplished a miracle in this politically divided capital city: it "united us, men and women, members of all parties, young and old." ${ }^{15}$

\footnotetext{
Modernity and the Weinar State, 1919-1933 (Princeton, 1998); Susanne Rouette, "Mothers and Citizens: Gender and Social Policy in Germany after the First World War," Contral European History" 30, no. 1 (1997): 48-66.

13. Harriet Anderson, Ltopian Feminism: Women's Movements in fin-de-siele Vienma (New Haven, 1992), 124.

14. On women in prewar politics, see Anderson, Ltopian Feminism; Birgitta Zaar, "Dem Mann die Politik, der Frau die Familie-die Gegner des politischen Frauenstimmrechtes in Österreich. 1848-1918," Österreichische Zeitschrift für Politikuissenschaft 16 (1987): 351-62.

15. Franenkriegskalender $1915,3$.
} 
Comprising the Frauenhilfsaktion Wien were the Imperial Organization of Austrian Housewives, the Social Democratic Women's Organization, the Catholic Women's Organization of Lower Austria, the Viennese Christian Women's League, and the League of Austrian Women's Associations. ${ }^{16}$ Membership statistics were as follows: the Housewives had 30,000 members in Vienna and in its satellite branches; the Social Democrats too had 30,000, also distributed in the capital and the crownlands; the Catholic Women's Organization of Lower Austria claimed 12,000 regular members; the Viennese Christian Women's League had between 13,000 and 20,000; and the League of Austrian Women's Associations boasted 40,000 members. ${ }^{17}$ These numbers are somewhat misleading because the league was an umbrella organization to which eighty smaller groups, including the housewives, belonged. Seventeen women from the member groups made up the executive committee of the Frauenhilfsaktion Wien, which was housed in the city hall and headed by Berta Weiskirchner, wife of Vienna's Christian Social mayor. The women set up twenty-three branch offices, staffed by 700 volunteers, and offered the following social services: they aided in collection drives, established information bureaus for people seeking employment or advice on matters relating to mobilization or collection of state aid, organized war kitchens in many districts, and provided training and work space for twenty-nine sewing rooms where approximately 7,000 unemployed "sisters" earned money sewing and knitting war garments.

While women of the middle and upper classes ran these various social services, the leaders of the Social Democratic women defended their decision to join the "ladies" in the Frauenhilfsaktion Wien. Quite simply, the material distress that many working-class families experienced at the beginning of the war due to conscription and the transition to a war economy warranted joining an organization dedicated to providing social services. By participating from within, the Social Democratic women wanted to ensure that the Frauenhilfsaktion

16. Die Franen-Hilfaktion Wien (Vienna, n.d.), 15. From my research it appears that the Allgemeiner österreichischer Frauenverein, a very small but intellectually influential group of women (primarily from Vienna), did not officially join the Frauenhilfsakion Wien, although its members were active in war services. The AöF sent the only Austrian representatives to the 1915 women's international peace conference in the Hague. The group wished to transcend the limits of "Austria's women" and appealed to "women of all classes and all empires." Friedershefte des Allgemeinen öterr. Frauen-Vereins: Frauen auf zum Kampf fuir den Frieden (probably 1917).

17. Because membership in some groups overlapped, "double counting" of members is possible here. Membership figures from the following: Granitsch, Kriegsdienstleistung, 10; ArbeiterinnenZeitung 27, no. 8 (9 April 1918), p. 1. The number of Social Democratic women may have been higher in 1914-the women's committee struggled to hold its members during the war; Tätigkeitsbericht der katholischen Frauenorganizationen für Niederösterreich 1917, AdR k.k. Min. soz. Verwaltung 1918, Jugendfürsorge carton 2472, \#289; John W. Boyer, Culture and Political Crisis in Vienna: Christian Socialism in Pover, 1897-1918 (Chicago, 1995), 502 (figures for 1901-1905); Anderson, Utopian Feminism, 91. 
would not become just another charity run by ladies for the benefit of the poor. Their constituents needed convincing. Leaders noted, "To our profound regret, we meet dependents of comrades who would rather starve and carry their hardearned possessions to a pawnshop than seek out the services" of the neighborhood branches of the Frauenhilfsaktion Wien. Working-class men feared, mistakenly, that accepting help from the Frauenhilfsaktion amounted to taking charity, which would disqualify them as voters under Austrian law. Social Democratic women leaders tried to assure their followers that the organization was not a charitable one, and that visiting a neighborhood branch need not be humiliating:

Often we hear from our female comrades that they don't want to "bow down before the Christians." This attitude has to be combated. First, the money doesn't come from the "Christians" alone, and furthermore, one need not feel humiliated - our female comrades have seen to that. ${ }^{\text {ik }}$

Nevertheless, they acknowledged that any visit to a committee of the Frauenhilfsaktion for work, food, or advice would probably entail an encounter with society ladies, since the latter had the most free time to donate to the cause.

While the creation of the Frauenhilfsaktion Wien was a considerable accomplishment and the organization provided vital services during the war, it was not representative. The key problem in using the published writings of women's groups to draw conclusions about women as a whole is that these groups represented only a small fraction of Viennese women. Even if we interpret the membership statistics of the Frauenhilfsaktion very generously, knowing that some women belonged to more than one group, that the membership lists counted women not just from Vienna but from the province of Lower Austria, and that membership may have been exaggerated, the organizations comprising the Frauenhilfsaktion represented no more than 12 percent of Viennese women. It is important to bear this in mind when considering the validity of claims that organized groups made on behalf of all women.

\section{Feminine Virtues}

Organized women's groups attributed unifying, almost magical powers to the war. They described war not as a social process in which they were participants, but as an anthropomorphic teacher of whom they were the students. "For our housewives, the war was a strict master (Lehrmeister)" who demanded diligent, efficient performance from his pupils. ${ }^{19}$ War revealed to them previously unseen connections between their private lives and the wider world: "With dazzling clarity the war showed us the threads that link our private economic concerns

18. Arbeiterinuen-Zeitung 24, no. 1, 5 Jan. 1915, pp. 3-4.

19. Oesterreichische Franen-Zeitung 1, no. 1 (1917), p. 7. 
with the whole political economy." What differentiates this war appreciation from the "war enthusiasm" that swept European home fronts in 1914 is the specific emphasis on the war's lessons for women. War called women to put aside the "political trivialities of yesteryear," to step out of their roles as private persons disconnected from the "large, serious, earthshaking questions" of the times. Of course, some women had already assumed positions in Austrian public life prior to 1914, notably in campaigns for women's education and employment opportunities, but even these women credited the war with "[teaching] us . . the triumph of women's work in the service of the whole." 11 In wartime, this service was not a choice, but an obligation. Hermine Cloeter, a Viennese war volunteer, explained, "Finally the day came when everything we [did] for ourselves appeared small and worthless: everyone wanted to do something for the whole." ${ }^{22}$ While women's groups expressed obligatory regret and sorrow at the coming of war, they also revered war and welcomed the lessons it would impart to them.

To minimize class, religious, or national differences, women's groups cited universal feminine virtues and appealed to each other's shared maternal instincts. One of these virtues was a capacity for love. Christa Hämmerle has noted a love discourse on the World War I Austrian home front in which women's talents for preserving and spreading love were counted as contributions to the war effort. Labor performed and services rendered were cast as "acts of love." ${ }^{23}$ As mothers (or potential mothers) all women, regardless of prior affiliation, were experts in nurturing and "drying tears"; they possessed natural defenses against the hate, vulgarity, and greed that mushroomed in wartime. ${ }^{2+}$ Women could soothe the pains of sudden geographic dislocation. A Jewish women's organization offering services for Jewish war refugees in Vienna explained what would happen when a female refugee arrived at its office:

Here she knocks. She won't be intimidated by the matter-of-fact sobriety of officials; she stands face to face with women, in whose eyes she sees knowing sympathy. She can also reveal her silent suffering to [the women], who take care of everything expeditiously with tact and feminine tenderness. ${ }^{25}$

20. Helene Rauchenberg, "Erziehung zum Frieden," lecture before the Bund öst. Frauenvereine, Vienna 1918.

21. Katharina Migerka, "Was der grosse Krieg uns lehrr," Almanach, 99.

22. Almanach, 18.

23. Christa Hämmerle, "'Zur Liebesarbeit sind wir hier, Soldatenstrümpfe stricken wir . .'. Zu Formen weiblicher Kriegsfürsorge im Ersten Weltkrieg," (Ph.D. diss., University of Vienna, 1996), 159.

24. Fraten-Hilfsaktion, 11; Der Bund: Zentralblatt des Bundes österr. Fratuenvereine 12, no. 9 (Nov. 1917), 12-13.

25. Anitta Müller, Ein Jahr Flüchtlingsfirsorge, 1914-15 (Vienna, 1916), 7. Jewish women saw their war work as an opportunity to serve Austria and fellow Jews simultaneously. See Marsha L. Rozenblit, "For Fatherland and Jewish People: Jewish Women in Austria During World War I," in 
In this scenario, as in countless depictions from ancient to modern times, women's love is seen as the antithesis of war. ${ }^{26}$

Other sources suggest, however, that extreme shortages of food and material resources in wartime Vienna tested the theory that women were selfless beings imbued with love. ${ }^{27}$ Censors at the War Ministry responsible for monitoring the mood of civilians described the spirit on the home front as anything but loving. The women in their reports are very different creatures from the women in patriotic writings whose "warm blood must now flow with love for all humanity"; who felt "unending sympathy" for "all victims of these times, for all, man and animal, friend and enemy"; who learned in war "the miraculous power of love." ${ }^{2 \pi}$ Rather, censors who spent their days reading women's letters noted "a marked rise ... in the antisocial instincts of particular individuals." "Envy and hatred" separated those who had become rich in wartime from those who felt left behind. "Striking are the recurring complaints of egotism, displayed among close relatives, among siblings, between children and parents." the censor's reports are rather more human than feminine; their virtues are balanced by selfishness and pettiness.

Similarly, women who threatened to abandon their maternal duties posed a challenge to the belief that mother love would sustain the home front and provide the grounds for a stable, nurturing postwar society. With too little evidence to call it a trend, but enough cases to make it noteworthy, we find in police and censors' reports strains of maternal defeatism on the home front. That is, women in desperate situations expressed their despair by threatening to kill themselves and their children. ${ }^{31}$ Hedwig Dussl, a 37 -year-old war widow from Vienna's XVI District notified the minister-president and the food office in March 1917 that, if she did not receive help, she would kill herself and her two children within days. Dussl's husband, a baker's assistant, had been killed early in the war and now her children were sick. Neighborhood police responded to her threat by delivering coal, lard, and vegetables, and making a note to "keep an eye" on her circumstances, ${ }^{31}$ Dussl's call for help was extreme, but she was not

Authority, Identity and the Social History of the Great War, ed. Frans Coetzee and Marilyn ShevinCoetzee (Providence, 1995): 199-222.

26. See Jean Bethke Elshtain, Women and War (Chicago, 1987).

27. For Vienna's wartime food crisis, see Maureen Healy, "Vienna Falling: Total War and Everyday Life, 1914-1918," (Ph.D. diss., University of Chicago, 2000), chap. 1.

28. Almanach, Käthe Braun, 15; Ella Hofer, 66; Katharina Migerka, 99.

29. Stimmung und wirtschaftliche Lage der österreichischen Bevölkerung im Hinterland. May Report. Kriegsarchiv, Kriegsüberwachungsamt [KA, KÜA] 1917, \#108758.

30. I consider the statistics on child murder and abortion in Franz Exner's Krieg und Kriminalitat in Österreich (New Haven, 1927) to be unreliable. Like many scholars from this time period, Exner draws conclusions about Austria using German statistics because the latter are "richer" and better organized according to sex, age, and family status. See pp. 146-66 for his discussion of women.

31. Police report on Hedwig Dussl. Archiv der Bundespolizeidirektion Wien [AdB1)W] 1917 St. $/ 27$ \#0663. 
alone. From market and street demonstrations police reported hearing verbal threats similar to Dussl's:

Many women hold their children above their heads and shout, somebody should take a look, they're already half-starved[.] [T] hey will hang one in every window, that's how far the government has driven them.

It would be best to take the children into the Danube or jump from the fourth floor...

The government... should give us cyanide instead of potatoes, then we wouldn't have to wait at four in the morning for $2 \mathrm{~kg}$ of this frozen rot.

Some women expressed general pessimism: "Someone should just shoot us or otherwise do us in, but don't just leave us slowly to die," while others made direct reference to their children. In a coal line in District X, a mother threatened, "There's still coal in the cellar but it belongs to the rich, we can go to hell; I'm going home now to hang my children." Children had no place in this society, according to one critic in district XVII: "Every pregnant woman should abort the child or strangle it at birth." 32 Such comments draw on, but invert, the maternalist discourse of the organized women's groups. While still identifying as mothers, women expressing maternal defeatism turned the theory of mother love on its head, reappropriating it as an instrument of protest.

\section{Reconciling Women and "Womenfolk"}

Some organized women's groups showed surprisingly little interest in the women who would have seemed to be their natural constituents, and others propagated theories of female collectivity that clashed with women's lived experiences. The Social Democratic women are a case in point. Police reports from 1916 onward record that tens of thousands of "womenfolk" were waiting in food lines on any given day in wartime Vienna. Many of the discontented shoppers were women of the working classes who, in angry statements to authorities or verbal assaults on shopkeepers, demonstrated a keen consciousness of their positions in the war economy. And yet, perusal of the ArbeiterinnenZeitung, the organ of the Social Democratic women's committee, shows that the committee distanced itself completely from the women in the streets; it held fast to the distinction between women of the underclasses (Unterschichten) and women workers (Arbeiterinnen). Losing membership during the war, the organization acknowledged that the food crisis was partly to blame. "As every woman has to spend many hours of the day to get a loaf of bread or a half kilo of flour, when is there time left over to think about the organization and newspaper?", 33 
Yet there is virtually no mention of (or support for) the forceful, physical presence of women at the markets. Like their male counterparts in the Social Democratic Party, the organized women clung to notions of discipline and party structure and distanced themselves from the female "rabble" in the streets.

The organization which spoke most fervently on behalf of female shoppers was the Imperial Organization of Austrian Housewives. In the interests of consumers, which it equated with women, or more narrowly, "we housewives," it advocated price controls on essential goods and waged a steady press campaign against profiteers:

Since the outbreak of war... we women ... have seen it as our task to fight against the internal enemies who, in these important and serious times and in most detestable pursuit of personal gain, have an eye only for their own profits. $^{34}$

But the categories "women" and "consumers" were not fully congruent; a considerable number of those arrested for profiteering were themselves women, and marketplace violence often consisted of skirmishes among women shoppers or the demolition of women's stands. In 1917, when a female market seller declared to assembled shoppers, "Somebody should burn this rabble," apparently referring to the shoppers, they destroyed her stall. Only "with effort" could the security personnel who intervened protect the seller from bodily harm. The same day a group of women and children who broke into a shop to steal three hundred loaves of bread had the saleswoman "by the throat" when policemen arrived..$^{35}$ Here women played protagonist and antagonist simultaneously. Solidarity at the market was based on a fleeting community of sufferers, but this community did not necessarily follow gender lines.

Nor could women planning a collective action count on female solidarity within the food lines. Josephine Waldhäusl reported to police in Vienna's X district in March 1917, that she had uncovered a conspiracy at the market:

I overheard a few women who looked like they belonged to the working class (Arbeiterstand), as one said to another, was she also planning to come next Sunday. The one asked where to, and the first answered "Yeah, on Sunday the fun begins. A demonstration"; another asked what kind of a demonstration, and where? The other: "Things are letting loose all over on Sunday on account of food and the like..."36

Waldhäusl could not identify the women because she did not know them and had no association (Gemeinschaff ) with them. Whether she reported them out of

34. Der Morgen, 21 June 1915, p. 14; 2 August 1915, p. 12.

35. Police report, 3 April 1917. AdBDW 1917 V/9 \#32385.

36. Protokoll from Polizei-Bezirks-Kommissariat Favoriten, 30 March 1917. AdBIJW 1917 St. $/ 20 \# 32385$. 
malice, fear, or a sense of duty, her situation points to a difficulty in reconciling the housewives' program of female solidarity based on shared interest as consumers. At the abstract level, the housewives were right that most consumers were women, who, as a collective, stood to gain by challenging monopolists and power brokers in Vienna's ailing food distribution network. As a lived experience, however, consumer solidarity was not synonymous with women's solidarity. Women themselves played multiple roles in the food crisis: consumer, producer, seller, profiteer, and victim.

In choosing the war as a time to celebrate women's unity and enlist their virtues in the service of the whole, organized women's groups set for themselves a formidable challenge. Their theories about woman's true nature were tested under the most materially difficult circumstances. By the second half of the war acute shortages had curtailed the actions of the Frauenhilfsaktion Wien. They lacked food for their war kitchens and cotton and wool for their sewing centers. Marianne Hainisch, head of the League of Austrian Women's Associations, warned soberly that material shortage posed a danger to women's potential collective spirit. She urged women in economic despair not to forget the war's important lesson that the "I" was connected with the rest of society. ${ }^{37}$ Viennese women conducted their daily lives in wartime not as a sisterhood, but as a collection of "I's" that sometimes unified along gender lines but often did not.

While organized women's groups failed in concrete ways to integrate women and womenfolk into an operative home front collectivity, their theories about women's nature took firm root at the state level. As the following four scenarios demonstrate- marriage to foreigners, payments to soldiers' families, cases of legal accountability, and the creation of the Women's Auxiliary Labor Force - women came into greater contact with state authorities and institutions than ever before, and these contacts were bounded on all sides by contemporary assumptions about women's nature. Cumulatively, these experiences demonstrate that feminine and maternal qualities hailed by the Frauenhilfsaktion Wien were codified publicly during wartime and formed the basis for women's citizenship in Austria.

\section{Citizenship and Gesinnung}

Austrian law made passing mention of women "enjoying the rights of citizenship," but these rights were never positively defined. Rather, women's citizenship appears only in a clause on women's loss of citizenship through marriage to a foreigner. Conversely, a foreign woman who married an Austrian was assumed to take Austrian citizenship by virtue of the fact that a wife "followed

37. Wiener Stadt- und Landesbibliothek, Zeitungsausschnitt-Sammlung [WSLB ZAS] Frauenarbeit I, Arbeiterzeitung, 9 Feb 1916. 
the Stand of the man." ${ }^{3 x}$ During World War I, however, law proved an insufficient means of distinguishing between "Austrian" and "foreigner." This distinction, charged in wartime because of the conflation of foreigner with enemy, was as likely to be based on sentiment or insinuation as on the law. Contemporaries accorded great significance to a concept that has since fallen out of use in discussion of citizenship: Gesinnung. Difficult to translate, Gesinnung referred to one's disposition, attitude, or political proclivities. Gerald Stourzh points to the importance of Gesinnung in assigning ethnic attribution to individuals in prewar Austria - that is, in deciding to which nationality within Austria a person belonged. ${ }^{39}$ Stourzh finds the evaluation of a person's Gesinnung to be an insidious, thoroughly subjective process- "one would have to look into their family relations and would have to take into account their behavior, conduct, and their views in all national questions" - and calls it "that terrible phenomenon to be found in all illiberal and chauvinistic movements ..." ${ }^{+11}$ In wartime we see that Gesinnung was used not only to determine national belonging, but also to test a person's loyalty to the state. Widespread in World War I, the discourse of Gesinnung permeated popular writings (letters of denunciation, for example) as well as police and court files in which labels such as "Russian-gesinnt," "Slavic-gesinnt," or "patriotic-gesinnt" were entered alongside objective traits such as date of birth, address, hair color, or height. Gesinnung was considered an innate trait, and a poor Gesimmung could infect an entire family.

The centrality of Gesimung to citizenship is evident in the 1917 case of a foreign-born woman in Vienna who faced criticism that her commitment to Austria was less than sound. Despite the fact that she had married an Austrian man, and thus by law had become an Austrian citizen, she could not live down persistent rumors that she was Italian. The rumors continued, despite her husband's proven loyalty to the state and her own impressive involvement in warrelated, charitable activities. Like countless women who thought and wrote about their duties toward and feelings for the state during the war, the "Italian" struggled to articulate her relationship to Austria. She differed from the many other women grappling with their civic identities at this time only in that she was the empress of Austria.

The case of Empress Zita highlights some of the key citizenship issues affecting all women, from nobles to those of the lower classes. Married to Franz

38. ABGB 3+ Patent, 2+ March 1832, \$19 states, "Die Frauenspersonen, welche das Stratsbürgerrecht geniessen, und welche sich mit einem Ausländer verheiraten, verlieren, indem sie dem Stande des Mannes folgen, hiedurch die Eigenschaft von österreichischen Unterthaninnen." Geller, Algcmeines bürgerliches Geserzbuch, 152.

39. Gerald Stourzh, "Ethnic Attribution in Late Imperial Austria: Good Intentions, Evil Consequences," in The Habsburg Legacy: National Idcutity in Historical Perspective, ed. Ritchie Robertson and Edward Timms (Edinburgh, 1994), 67-83.

40. Ibid., 71 . 
Joseph's successor, Karl, who became emperor in late 1916, Zita lent her name to charity organizations and frequently visited soup kitchens and volunteer stations in Vienna in order to boost morale. But she was also the subject of much gossip and could not shake the label "foreigner." A contemporary remembered from an opening of a war kitchen, "[She spoke] with an unmistakably foreign (fremdländischem) accent. Perhaps this is one reason why she is considered a foreigner by the population." +1 Zita is remembered in relation to her brother, Prince Sixtus, who negotiated the secret French-Austrian communication (a compromise peace, loosening the German-Austrian alliance) that was later exposed and caused scandal and humiliation for the Austrian imperial family. ${ }^{+2}$ Her French and Italian lineage (she was from the house of Bourbon-Parma) did not endear her to Austrian patriots in wartime. A number of sensational stories circulated in the Zita rumor mill: she was reported to have betrayed Austrian troops engaged in battle against Italians on the Piave river; she allegedly "fired two gunshots" at the German Emperor Wilhelm; and she was rumored to have been locked up in a Hungarian castle to prevent her from doing more damage to the Austrian war effort. In all of these instances, police identified and arrested women of the lower classes for slandering the imperial family. ${ }^{43}$ Zita's Christian Social defenders painted her as the mother of Austria. Countering these "most despicable rumors" at a rally, they contended she was "mother of the poor" who gave Christmas parties for children, founded convalescent homes for soldiers, and allowed royal horses to be used to transport coal to poor neighborhoods in Vienna. ${ }^{+4}$ In Zita's roles as both first lady and state enemy Austrianness was less a matter of law than of how people in the street evaluated her Gesinnung. Zita herself considered her Italianness an accident of birth: "[W]e were all 'Austrians' in Gesinnung, regardless of where we happened to be born." +5

Lesser known women in Vienna faced similar difficulties in establishing their Austrianness. A women's newspaper reported, "The arrangement whereby a woman automatically changes her citizenship to that of the man upon marriage has proven disastrous for women during this war." ${ }^{\text {th }}$ In the three cases

41. Hans Loewenfeld-Russ, In Kampf gegen den Hunger: Aus den Erinnernngen des Staatssekretärs fiir Volksermïhrmig, 1918-1920 (Munich, 1986), 100.

42. See Erich Feigl, Kaiserin Zita (Vienna, 1977); Gordon Brook-Shepherd, The Last Eimpress: The Life and Tines of Zita of Austria-Hungary, 1892-1989 (London, 1991); and Enilio Vasari, Zita: Kaiserin und Köniqin (Munich, 1976).

43. Police and governor's reports on rumors about the imperial family. Niederösterreichisches Landesarchiv, Präsidialakten [NÖLA Präs.] "P" 1918 Ib, 2603.

44. "Eine vaterländische Massenkundgebung in Wien," Reichspost, 2 July 1918, cited in Feigl, Kaiserin Zita, 336-39.

45. Feigl, Kaiserin Zita, 27.

46. Newes Fratenleben: Organ der freiheithichen Franen in Osterreid 19, nos. 11-12 (November/ December 1917): 226. 
considered here, those of Maria Mosconi, Frau Chr. P., and Maria SwiatopulkMirska, women faced the reverse problem of the empress: they were "born Viennese" but had married foreigners. Their legal citizenship status (unlike that of the empress) did not mesh with what they felt themselves to be. Mosconi and Swiatopulk-Mirska were both separated, but not legally divorced, from their husbands. Under Austrian law at the time, divorce was illegal for Catholics, and the only possibility for ending a marriage lay in obtaining a legal separation. ${ }^{47}$ Bound for life to their foreign husbands, the women in these cases used two strategies for establishing their Austrianness: first, they presented evidence of service to the state by male family members, usually husbands, fathers, or brothers. Second, in light of the novel labeling of women's work as Kriegsdienst, they presented records of their own service to the state.

In a last ditch effort to save her reputation and reclaim her job as a bilingual office worker in the Italian war zone, Maria Mosconi penned a dramatic letter to Emperor Karl in 1918. She wrote that she had inherited loyalty to the Habsburg dynasty through her "father's blood," and had ingested it through her "mother's milk." Born in Vienna, Mosconi had married an Italian and was still classified as an Italian citizen, despite having been legally separated for fourteen years. She worked briefly as a "female laborer" (weibliche Hilfskraft) in the Italian zone, before military authorities fired her on grounds of political unreliability. She was allegedly fraternizing with Italian citizens in her free time and was reputed to be a "hysterical" gossip who "prattled on" indiscriminately. While not technically considered a spy, her superiors noted that "on account of her verbosity and craftiness she was certainly in a position to do harm here." ${ }^{48}$ Back in Vienna, Mosconi mounted a defense that revealed her complicated relationship to Austria, mediated through her male family members. Her Austrian lineage was impressive: she was the daughter of a decorated field marshal lieutenant and the granddaughter of a general. "[U]pon our heroic march into Italy, I placed myself voluntarily in the service of His Majesty's Army High Command," she wrote, adding that she wanted to "achieve distinction" as an office worker in the same place where her father had done so in battle. But Mosconi was caught between being an Austrian's daughter and an Italian's wife. Despite her claim of willingness "to die for my adored, one and only Austria," she was confined to her Vienna apartment. Unable to support herself

47. A legal separation, "Scheidung von Tisch und Bett" (literally, separation of table and bed), allowed partners in a failed marriage to take up separate households. Divorce (Trennung) was permitted only for non-Catholics. ABGB $\$ 111,115$. See John W. Boyer, "Freud, Marriage, and Late Viennese Liberalism: A Commentary from 1905," Journal of Modern History 50 (March, 1978): 72-102; and Ulrike Harmat, "Die Auseinandersetzungen um das Ehescheidungsrecht und die sog. 'Sever-Ehen,' 1918-1938," (Ph.D. diss., University of Vienna, 1996).

48. Report from Walzel, Nachrichtenstelle Udine, 14 April 1918. Kriegsarchiv, Militärkanzlei Seiner Majestät [KA, MKSM] 1918 69-9/47. 
financially, she remained under a cloud of suspicion, branded a traitor (Landesverräterin) ${ }^{49}$

Lamenting the situation of women like Mosconi, journalist Olga Misar wrote that the war had forced women to protest "how really shameful it is that a woman does not possess personal citizenship" independent of her husband..$^{50}$ Besides affecting a woman's reputation in the community, the citizenship designation could prevent a woman from supporting herself. Frau Chr. P's situation highlighted the absurd consequences of the citizenship law in wartime. Described as "ein echtes Wienerkind" she was born in Vienna and had never left the city. A newspaper account of her case included the obligatory recounting of her male family members' contributions to Austria: her father had served in the Italian campaign of 1859 and had ended his life as a "servant of the state." This was little help to his daughter, however, who had married a Serbian citizen living in Vienna and consequently ran into great trouble at the outbreak of World War I. Her husband was interned in a prison camp in the nearby town of St. Pölten. As a Serb Frau Chr. P. was not eligible for community welfare payments and had to apply for financial support from the Serbian state. She was informed that in order to receive benefits she would have to move to Serbia (not an easy prospect in 1915), where she had never been. She turned instead to a branch of the Frauenhilfsaktion Wien, asking for help in acquiring a sewing machine so she could support herself. The Frauenhilfsaktion was sympathetic, but informed her, "We are unable to grant this favor to the subject of an enemy power." ${ }^{\prime 1}$ Frau Chr. P. was thus labeled an enemy in her own hometown.

Women caught in the citizenship trap during the war were left to make the plea that they felt Austrian. Many of the arguments made to support this feeling are found in the writings of cabaret pianist Maria Swiatopulk-Mirska, whose articulate expressions of her relation to the state contain many of the themes relevant to women's citizenship at the time. Branded a Russian because of an earlier marriage that ended in legal separation, Swiatopulk-Mirksa employed a wide range of arguments in her campaign to uphold her right to perform on stage in wartime Vienna, though a citizen of an enemy state. ${ }^{52}$ First, she stated her premarital Austrian credentials: "I have already documented that I am an Austrian citizen by birth." Next she argued for the irrelevance of her legal status as a Russian, asserting that it had not affected her Gesinnung: "As a Pole and an Austrian, I myself am thoroughly patriotic-Austrian gesinnt." (Her claim to be both a Pole and an Austrian was perfectly understandable to contemporaries. Within supranational Austria, one's loyalty to the state was not

49. Letter from Maria Mosconi to Kaiser Karl, 24 May 1918. KA, MKSM 1918 69-9/47.

50. WSLB ZAS, Rechtsleben und polizeiliche Massnahmen III, Neues Wiener Tagblatt (Abend), 26 January 1917.

51. "Ein Jahr Frauenhilfskomitee--Die Feindin," Arbeiterinnen-Zeitung (24 August 1915): 3-4.

52. Letter Maria Swiatopulk-Mirska to police. NÖLA Präs. "P" XVIII, 396. 
incompatible with simultaneous membership in one of its nations.) She then presented a list of several male family members' military and civil service for Austria. Thus, while she did not want to share the status of her ex-husband, she did want other male family members' accomplishments added to her own citizenship dossier. Finally, she presented herself as a hard-working, single mother whose maternal desire to care for her Austrian child was being thwarted by an unjust law. On account of the police ban, she was "completely unemployed and in no position to earn an honest living... [for] myself and my child." Her rhetorical strategy was to cast a wide net in hopes that the authorities would find at least one of her arguments compelling. They did. Swiatopulk-Mirska was eventually granted the right to perform; on the surviving copy of her letter, the only bureaucratic markings are blue lines highlighting the service of her uncle and brothers.

We might ask why male service remained so crucial in determining a woman's status at a time when women could claim their own gender-specific Kriegsdienst for Austria. I believe the answer to this question goes beyond the patriarchal traditions of Austrian family law, under which women and children were legally dependents (Angehörige) of the male head of household. Gesinnung, the proclivity for loyalty or disloyalty to the state, was widely thought to be a trait not of individuals, but of whole families. Thus, the logic of Gesinnung did not allow for variation within families. The problem, of course, for all of the women discussed here was that they belonged to two families - the birth family and the marital family. We see little sign that authorities were eager to factor in a third component - a woman's own proclivities, as demonstrated by volunteer or paid service during the war - in evaluation of Gesinnung.

Authorities charted the Gesinnung of suspicious families in the same way that turn-of-the-century criminal anthropologists charted generational degeneracy: with the aid of a family tree. ${ }^{53}$ Political unreliables were interned in prison camps or confined to house arrest in Vienna. With notable exceptions, women were thought to absorb Gesinnung from male family members. In the case of a Russian Orthodox family in Vienna, the father had "made himself and his family conspicuous." "This family" the police reported, "is said to be russenfreundlich

53. For cxample, in 1917, military authorities made a diagram the size of a field map of the Kreutzenberg-Ecchers, a family accused of Italian irredentism, and provided a key explaining the crimes or suspicious activities of forty-five family members over four generations. The few upstanding members of the fanily, including a Major General in the Austrian army, could not make up for the dozens of bad seeds; the family was incurably "national gesinnt." On occasion, it was not the male members whose behavior and attitudes determined the Gesimnmg of the whole family. In the case of the Kreutzenberg-Ecchers, officials deemed Eugenia von Kreutzenberg, wife and mother, a "fanatical ltalian" and "the most politically dubious person, the prime mover in the family, who wielded influence" over her husband and sons. Stammbaum der Familie Eccher; k.u.k. 11. Armeekommando to k.u.k. Heeresgruppenkommando FM Freiherr von Conrad, 18 June 1917. KA, MKSM 69-8/8 1917 
gesinnt." ${ }^{5+}$ In another case, Sophie Markow, widow of a "Russian agitator," arrived in Vienna in 1915 as a refugee from Lemberg with her three daughters. They were placed under police surveillance because "in Lemberg the whole Markow family is known for its avidly Russophile Gesinnung." ${ }^{55}$ An anonymous letter to the police in Vienna's Favoriten district warned of the arrival of an entire family of suspicious Czechs. The denouncer claimed that "an ultraCzech, Russophile, Serbophile family" had recently moved to the neighborhood after things got a little too "hot" for them in Brno. ${ }^{56}$ Gesinnung was an ambiguously defined, highly charged, and officially sanctioned way of reading an individual's loyalty to the state. It passed like a germ, usually from husband or father to the rest of the family, and transformed the family into a unit of guilt by association.

These subjective ways of assessing state loyalty in wartime help explain why a woman's legal citizenship was sometimes of secondary importance when compared to other social determinants. On some occasions, as in the case of Empress Zita, rumors of an anti-Austrian Gesinnung could seriously undermine a woman's (legally sound) claim to be Austrian. In the other cases, such as Maria Mosconi's, Frau Chr. P.'s, and Maria Swiatopulk-Mirska's, women argued that hometown loyalty or patriotic Gesinnung trumped their legal status as foreigners. The criteria for identifying a woman's standing vis-à-vis Austria included any number of extralegal determinants: her accent; military or civil service by male family members; her commitment as a mother; and the attitudes inherited from generations of descendants. Nancy Cott's thesis that citizenship is a spectrum rather than a firm status is useful here for understanding Austrianness. Often it was not a question of whether a woman was Austrian (the law was clear enough in most cases) but a determination of how Austrian she was, based on a host of family-related variables.

\section{The Surrogate Husband}

The familial basis of women's citizenship outlined in the individual cases above was replicated on a societal scale with the advent of state aid to families of soldiers during World War I. Women's familial roles became publicly codified in a system of welfare payments. Across Europe, women entered into new financial relationships with states during World War I. In every combatant country, states paid economically dependent family members subsidies to cover some or all of the support they had previously received from their men who were now enlisted. Historian Susan Pedersen describes a situation in Britain

54. Report on Barna family. NÖLA Präs. "P" 1915, IV, 297.

55. Letter to Statthalterei, 4 March 1915. NÖLA Präs. "P" 1915, VII, 1210.

56. Anonymous letter from Brünn to Pol Kommissariat Favoriten. Adl3DW 1916 St. $/ 9$ \#30703. 
where the state came to play the role of "surrogate husband," paying wives "because of their husbands" citizenship status and rights, not their own work or needs." ${ }^{57}$ In Austria, the logic of the payments, known as the "state support subsidy" (staatlicher Unterhaltsbeitrag), was similar; women were paid subsidies on behalf of their husbands' service to Austria. The Arbeiter-Zeitung explained, "The state that doesn't protect soldiers' wives against hunger wouldn't be worthy of the spilled blood of its soldiers." ${ }^{58}$ The millions of women who went twice a month to pick up their payments, issued by the Austrian War Ministry and distributed by municipalities, were forging a novel but dependent relationship with the Austrian state. According to state censors who tracked public opinions of the payment scheme, the experience led to "disorientation," "bitterness," and profound disappointment for many women. ${ }^{59}$

The difficulty of implementing the payment scheme for millions of recipients who were now temporary dependents of the state led many women to feel victimized, rather than subsidized, by Austria. Only three weeks into the war, one could hear "bitter complaints" about the mismanagement and injustice of the payment scheme. ${ }^{60}$ The first official review of the program concluded, "It appears to be an undeniable fact that, despite its truly humane and social intentions, the program of state support subsidies has not met with the anticipated popularity." ${ }^{\prime 11}$ By June 1917, the Austrian government had paid out an astounding 3,676,250,342 crowns in support to soldiers' families. ${ }^{62}$ By October 1918, Viennese residents, the vast majority of them women, had filed 467,321 applications for the state support subsidy. The payment scheme, first updated for inflation in 1917, was based on a 1912 law that stated:

Family members (wife, children, parents, grandparents, parents-in-law, stepparents, siblings, and also illegitimate children) of conscripted Austrian citizens whose livelihood was heretofore dependent primarily on the wage of the conscripted citizen, have right (Anspruch) to a support subsidy, which for each dependent consists of a support payment ( $88 \mathrm{~h}$ for Vienna) and a rent subsidy (44h for Vienna). ${ }^{63}$

57. Susan Pedersen, "Gender, Welfare and Citizenship in Britain during the Great War," $A H R$ 95, no. 4 (Oct. 1990): 983-1006, 985.

58. WSLB ZAS Frauenarbeit III, Arbeiterzeitung, 23 June 1918.

59. Censor's reports "Der staatliche Unterhaltsbeitrag," 31 March 1917, 5 June 1917 and 3 March 1918. KA, Armeeoberkommando-Gemeinsames Zentralnachweisbüro [AOK GZNB], 1917 carton 3751 \#4614, \#4675; AOK 1918 GZNB carton 3757 \#5033.

60. WSLB ZAS Staatliche Unterstützung I, $A Z 22$ August 1914.

61. Report on state support subsidies, 31 March 1917. KA, AOK GZNB, 1917, carton 3751, \#4614.

62. Denkschrift über die von der k.k. Regierung aus Anlass des Krieges getroffenen Massnahmen 4 (Vienna, 1918), 257.

63. Law of 26 December $1912 \mathrm{RGBl}$ Nr. 237, cited in Kriegszustand. Instruktionen für Polizeiorgane (Vienna, 1914), 19-20. A dense 1918 pamphlet "Was bekommen jetzt die 
Problems with the plan fell into three categories: most women felt the payments were too low, some felt they were wrongly denied payments, and a few challenged the program's public replication of women's familial dependence. Authorities compiled complaints from recipients' letters, and the women's voices cited below are drawn from these official reports. Despite the fact that inflation in wartime Vienna raged as high as 200 percent, the daily payment rate of $1.32 \mathrm{~K}$ per dependent ( $88 \mathrm{~h}$ for children under eight) remained set until 1916 , when rates for young children were increased by 25 percent. Only in 1917, with the reconvening of the parliament, was the rate for women and older children raised to $2 \mathrm{~K} .{ }^{64}$ Many women complained that when they sought outside employment to "supplement the supplement" they were denied state funds altogether. "I'm being punished because of honest work," charged one woman. ${ }^{65}$ In other instances, a Viennese woman was cut off for earning small amounts of money as a newspaper carrier; a landlady was scratched from the rolls because she had a vacant apartment; other women lost their payments for taking in needlework at home. ${ }^{66}$ Mayor Richard Weiskirchner lobbied Austrian authorities on their behalf, noting frequent cases in which women earning "only modest wages" had been cut off. He pointed out that the payment was defined as a Beitrag - a contribution - meant only "to prevent a threat to livelihood," not to prohibit women from earning additional wages. ${ }^{67}$

Other women were frustrated by multiple, unexplained rejections of their applications for the state support subsidy. Letters from the home front to men in the field contained "countless cases in which the news read "[W]e are doing badly, we aren't receiving the support subsidy." Authorities summarized complaints in 1918: "Some individuals report ... that they have applied repeatedly, three times, even six times," only to be met with "rude, arrogant words or to be shown the door" by bureaucrats..$^{68}$ Widespread misunderstanding about who was eligible for the state support subsidies left women frustrated. Some considered the payments a form of charity, a notion that state officials tried to dispel. From home front letters, censors surmised that people were not sufficiently educated about the "character and premise" of the wartime subsidies and "appear[ed] to see it as a kind of poor relief." This confusion was exacerbated

Soldatenfamilien?" shows that the 1912 law, with its wartime changes and additions, had become indecipherable to the average recipient.

64. "Neuregelung des staatlichen Unterhaltsbeitrages," Law of 27 July 1917, RGBl. Nr. 313. WSLB 67052C Kriegssammlung Konvolut 2.

65. Report on state support subsidies, 31 March 1917. KA, AOK GZNB, 1917, carton 3751, \#4614.

66. Comments of Gemeinderat Reumann and Skaret. WSLA B23/73 Gemeinderat. Protokoll der Obmänner-Konferenz, 1 December 1914.

67. WSLB ZAS Staatliche Unterstützung II, NWT, 5 August 1915.

68. Third report on state support subsidies, March 1918. KA, AOK 1918 GZNB carton 3757, \#5033. 
in Vienna by the fact that women picked up their state support subsidies at the same neighborhood offices that dispersed municipal welfare payments. The city government in turn complained that the inadequate wartime subsidies were driving people, "left completely helpless by the state," onto traditional city welfare; this was a breach of the state's obligation to soldiers, "whose mighty task should not be made more difficult by worries about the fate of their dependents." ${ }^{64}$

Although women and children received the state subsidies, the payments were in fact meant as compensation for the missing male wage earner. If the soldier deserted or otherwise violated military law, payments to his family were suspended. If he died, the payments were reduced by more than half. "7" While scorn for soldiers' wives never reached the pitch it did in Germany, ${ }^{71}$ Viennese women receiving the support subsidy were criticized for being frivolous with state funds. These "welfare women" (Unterstïtzungsweiber) were accused of wasting money intended for their husbands, money that came into their hands only by chance of war. Some critics even suggested that women who had married during wartime had done so to take advantage of the payment scheme. A speaker of the Association for Reform of Marriage Rights in Vienna complained about the phenomenon of war marriages, calling them "fleeting, reckless" unions created only to "activate the support subsidy." hardly credible, considering the agreement across the political spectrum-from Christian Socials to Social Democrats - that the payments did not provide subsistence, and the fact that marriage rates did not increase during the war. ${ }^{73}$

Social Democrat Emmy Freundlich came close to challenging the whole premise of the state playing surrogate husband to women in war. Austria, she maintained, ought to pay female citizens for their own hardship, which was equal to, if not greater than, the suffering of Austria's men:

$[\mathrm{N}]$ obody would be in a position to decide whether it is more painful and more torturous to experience the misery of the front, or to sit at home for months shaking about the existence and fortune of the family. The daily wor-

69. WSLB ZAS Staatliche Unterstuitzung I, Frendenblatt, 28 January 1915; II, Amtsblatt der Stadt Wien, 14 January 1916.

70. "Was bekommen die Hinterbliebenen der Gefallenen?" AZ, 25 November 1914.

71. On Kriegerfrauen in Germany, see Daniel, War from Within, 182-85; and Davis, Home Fires Burning, 33-40. On soldiers' wives in Russia, see Barbara Alpern Engel, "Not by Bread Alone: Subsistence Riots in Russia during World War I," JMH 69 (December, 1997): 696-721.

72. Police report on meeting of Eherechtsreformverein, 15 May 1918. NÖLA Präs. "P" 1918, XVb, 2176.

73. After a surge in marriages $(4,929)$ in August 1914 , the monthly marriage rate returned to prewar levels (around 1,000 per month), and did not vary much throughout the war. Another surge is evident in the second half of 1919. Mitteilungen der statistischen Abteilung des Wiener Magistrates, Monatsberichte, 1914-1919. 
ries, the punishing battle between hope and fear often amounts to more mental suffering and spiritual death than does actual death at the front. ${ }^{7+}$

Freundlich called for doubling the support subsidy and eliminating the differentiated pay for younger children: "That is what Austria's mothers demand from the state, from the government, and from society." ${ }^{75}$ Her demand that women be paid for wartime hardship as citizens in their own right fell on deaf ears.

The support subsidies represented a grand-scale intervention of the Austrian state into the families of its soldiers. They replicated in the public sphere the dependent status of women within the family, so that women remained, in the eyes of the state, wives and mothers. The state supported Austria's women only on behalf of Austria's men. While authorities conceived of the subsidies as "truly humane and social," the program did not keep pace with inflation, and the aid did not come close to covering the lost incomes of conscripted men. Female recipients rightly concluded that the Austrian state, which had long been depicted by imperial image-makers as a familial state with the kaiser acting as the father of his peoples in practice made for a poor surrogate husband and father.

\section{"Nature" and Legal Accountability}

Unable to ameliorate civilians' economic distress, officials administering the state subsidies program received a barrage of criticism. As we have seen, some women put pen to paper and sent their complaints to the authorities directly. Others engaged in widespread public grumbling about the economy, the government, or the course of the war itself. Dealing with these disaffected women fell to the police and the courts.

Because of their special nature as dependent creatures embedded in the family, women in World War I Vienna were held to a different standard of legal accountability for their speech and actions than men. Naiveté, inability to grasp abstraction, emotional rather than rational thought processes, and capriciousness were attributes that ostensibly justified women's exclusion from official politics in pre-World War I Europe. ${ }^{76}$ Volunteers of the Frauenhilfsaktion Wien declared at the outset of war that women were emotionally and intellectually ready for politics, and yet these traditional feminine traits lingered in the minds

74. WSLB ZAS Staatliche Unterstützungen II, $A Z 24$ November 1916.

75. Ibid

76. For example, Austrian law held that a woman was less capable than her husband of administering her own property. And women, along with children, the insane, the blind, the deaf, and the mute (among others) could not legally serve as witnesses. Oskar Lehner, Familie-Recht-Politik: Die Entwicklung des österreichischen Fanilienrechtes im 19. und 20. Jahwhundert (Vienna, 1987), 21, 27. For a nineteenth-century Austrian discussion of women's inferior brain functioning, see Zaar, "Dem Mann die Politik. .," 
of state authorities as they weighed the motivations and appropriate punishments for women's wartime protest.

Because Austrian law prohibited women (as well as children and foreigners) from joining political associations, all of these groups operated in the shadow of politics, casting their activities as social or charitable. ${ }^{77}$ Women's groups had argued for the abolition of this clause and were close to succeeding on several occasions before the war. Marianne Hainisch, head of the League of Austrian Women's Associations (one of the key groups in the Frauenhilfsaktion Wien), argued during the war that banning women from official political bodies deprived the state of their services. "With increased zeal, women will give to the state what belongs to the state - their energies, their love, their understanding - when they in turn are given what they are due." 78 She was referring to suffrage and the right of association, political rights of a formal kind. Over the course of the war, however, Austrian authorities were confronted with forms of women's political action that fell outside the realm of organized politics: women were speaking publicly about matters of state, criticizing government figures or their policies, and committing deeds (such as harboring deserters) deemed harmful to the state. In assessing how to punish these words and deeds, the state found itself with a conflict of interest. On one hand, to maintain morale on the home front it needed to curb critical (and illegal) statements about the conduct of the war, and to punish those who dared to make them. On the other hand, the state needed the services of women as mothers and caretakers on the home front, services it was denied if it imprisoned the thousands of women who spoke and acted critically of the state.

At the center of this conflict of interest were two of the most common crimes in World War I Austria: the relatively obscure charge of Majestatsbeleidigung - insulting his majesty - and the charge of disturbing the peace. ${ }^{79}$ Some authors have written comic accounts of the absurd application of these laws at the outset of war. ${ }^{80}$ The clauses are worth quoting here because they were the means by which many women in Vienna ran afoul of the law and faced imprisonment. The law on "insulting his majesty" stated,

Whoever damages respect for the kaiser, whether by personal insult, by slander or ridicule in public or in the presence of several people, through printed works, communication or distribution of pictorial depictions or writings,

77. $\$ 30$ of the Austrian Law of Associations, 15 November 1867.

78. Marianne Hainisch, "Petition an das Abgeordnetenhaus," Der Bund 12, no. 9 (November 1917).

79. These are $\$ 63$ and $\$ 65$ respectively of the Austrian penal code. In the years $1909-1913$ only a handful of people-all of them male-were arrested in Vienna for these crimes. Statistisches Jahrbuch der Stadt Wien, 1914 (Vienna, 1918), 306.

80. See Jaroslav Hasek, The Good Soldier Schweik, Book I, chaps. 1-2; and Karl Kraus, Die letzten Tage der Menschheit, Act I, scene 1. 
is guilty of the crime of insulting his majesty and is to be punished by one to five years imprisonment with hard labor. ${ }^{81}$

In wartime, criticizing the government, the state, the military or even complaining about conditions could be interpreted as an insult to the kaiser, in whose name the war was being waged. Comments as vague as "Down with the war!" or as specific as "Kaiser Franz Joseph has several illegitimate children," or "Our kaiser . . shouldn't have broken the alliance with Italy - then Italy would have helped us against Russia and I wouldn't have lost my son," landed women in jail. ${ }^{82}$ The charge of disturbing the peace was more broadly defined: it included expressing (in print or "in public or in the presence of several people") disdain or hatred of the kaiser, the kaiser's allies, the form of government, or the state administrators, disobeying laws, or encouraging others to commit these acts. Viennese women were arrested for comments such as "Germany must be defeated," "The Germans are stupid," "Someone should stick the German kaiser's nose in corn meal!" and "The Sarajevo murders were a good thing... the poor Serbs [did] too little." ${ }^{83}$ Women uttered these and thousands of similar opinions not in print or from podiums, but in food lines, in stairwells, and in conversations with "friends" in private apartments.

In these instances, Austrian authorities faced a difficult question: could and should women making such statements be held legally accountable for their actions? A vast administrative network comprised of local police and censors at the war ministry was dedicated to promoting and protecting a positive mood on the home front. Critical comments like those above, made in passing, could easily spread as rumors and undermine official proclamations. But the fact that they were made by women left authorities in a quandary. First, as noted above, the nineteenth century bequeathed to contemporaries a belief in women's inability to understand the gravity of politics. According to police, women critical of Austria often didn't understand the significance of their words or had "lost their heads." Second, jailing female offenders during the war further threatened the family, a delicate unit already strained by male conscription and a perceived increase in youth delinquency. To imprison women who had taken over their husbands' business obligations, who cared for children as the sole remaining parent, and who provided for other dependent relatives was, as legal experts acknowledged, not in the best interest of Austria. Ultimately legal authorities would have to decide: should women with critical opinions be held

81. For a full and lively account of this law, see Elgin Drda, "Die Entwicklung der Majestätsbeleidigung in der österreichischen Rechtsgeschichte unter besonderer Berücksichtigung der Ära Kaiser Franz Josephs," (Ph.D. diss., University of Linz), 1992.

82. Elise Bergtagnolli [also Bertaguolli] and Anna Burger, MKSM recommendations for imperial pardon. KA, MKSM 1917 85-1/10;85-1/65.

83. KA, MKSM 1916 85-1/36; AdBDW 1916 St./9 \# 35306 and \# 27535. 
accountable by Austrian law as individuals? Or should they be pardoned because the state valued them more as Austrian wives and mothers?

A set of applications for women's legal pardons and the rulings of imperial advisers on these applications allows us a glimpse of how gender played out in World War I jurisprudence. In the thirty-six cases from 1916 and 1917 under consideration here, women imprisoned for making antistate comments or insulting his majesty (23), for harming the state by harboring a deserter (9), for encouraging a man to abandon his military duty (2), for attempting illegally to secure a man's exemption from service (1), and for killing a man in service (1) wrote petitions for leniency (Gnadengesuch) to the kaiser requesting a shortening of sentence. ${ }^{8+}$ The cases cannot be considered a representative sample of all women who appealed for leniency because all of the cases cited here had positive outcomes. How many similar requests were rejected cannot be determined from archival records. These positive cases do, however, shed some light on the gendered logic of citizenship. In each of the cases below, imperial advisers supported leniency on one of three gendered grounds: as a woman, the accused did not have the mental capacity to understand the gravity of her words or deeds; as a mother, her imprisonment would place her children in peril; or, in the case of harboring a deserter, her loyalty to husband or son "naturally" took precedence over her loyalty to Austria.

In the first instance, women were granted leniency by claiming absent mindedness, a tendency to become overly excited, or on grounds of political naiveté. For all of the early-war rhetoric on the ways in which the war stirred in women a new political consciousness, these cases show that women were still not considered fully accountable as rational individuals. Therese Bartsch, a twenty-seven year-old grocery clerk in Vienna found herself in jail for having shouted to four soldiers who marched by her shop with a flag, "Stick the flag in the oven and stay home so the war will finally end!" Her sentence was reduced from six months to six weeks because she had shown remorse and had been in a state of "excitement" at the time of the offense. She was "nervous" because she hadn't heard from her husband in the field in a long while and wasn't sleeping well on account of her worries. Her unpremeditated comments were the product of her "highly agitated mood" and lacked "malicious intent." In this case, Bartsch's feminine attributes-her emotional vulnerability and excitability-reduced the force of her critical comment. ${ }^{85}$ The same logic applied to the case of Ludmilla Kubart, a thirty-four year-old midwife who predicted, while standing in the doorway of her Vienna apartment building, that "Germany and Austria

84. KA, MKSM 1916,1917 85-1. The women were tried in army district courts in Vienna, Linz, Brünn, Prague, Theresienstadt, Josefstadt, and a few smaller military court branches. Shortly after these cases were processed, Kaiser Karl's general amnesty of 2 July 1917 freed many female offenders jailed on charges of "insulting his majesty" and disturbing the peace.

85. Ibid., 1916 85-1/71. 
will become this small," whereupon she traced a small circle on her palm. Among the other reasons for her release, advisers noted that she had made "a comment . . . among women that posed no wider threat." Kubart's eight-month sentence was reduced because she did not show signs of an antistate Gesinnung, and appeared to be an "easily excitable person."

Even in crimes of greater magnitude committed during wartime, women's perceived emotional fragility worked in their favor. In 1915, Marie Wanko stabbed her husband Richard, a military reservist, to death in their Vienna apartment. She received a reduced sentence in part because she had committed the crime in a "highly agitated state," and was judged to have "hysterical tendencies" that were exacerbated by menstruation and alcohol consumption. ${ }^{87}$ By recommending leniency for a woman on account of her predilection for gossip, her inexperience in "political matters," or because she was judged "incapable of mature reflection," the women's groups' newfound regard for women's political onsciousness.

The kaiser was equally likely to pardon women on grounds of motherhood. Jailing a woman on the home front might mean removing the only remaining parent in a family that had already been disrupted by conscription. Embarrassing situations arose when women tried to bring their children to jail with them because they had no other childcare options. ${ }^{89}$ Authorities needed to protect the state from slanderous remarks, but they also feared an increase in the number of abandoned children that would result from punishing female offenders. They needed women's help in combating the youth delinquency epidemic that had spread through the city in early 1916. Arguing for the early release of a mother of three children, officials noted, "In every single case, where possible, steps should be taken against the ever more alarming [rise of] youth delinquency." "' The kaiser's advisers recommended early release for Käthe Srsen, mother of a nine-month old baby, arguing that the "health and perhaps even the life of the child would be endangered" if she served her full sentence for aiding and abetting a deserter. ${ }^{11}$ In the case of Elise Bertagnolli, authorities reduced a two-year sentence, which suggests they considered insulting the kaiser - the offense Bertagnolli had committed-less a threat to Austria than the continued incarceration of a mother of eleven children. Whatever threat to public morale women posed as war critics, the value of their maternal services on the home front weighed heavily in their favor when seeking leniency for these offenses.

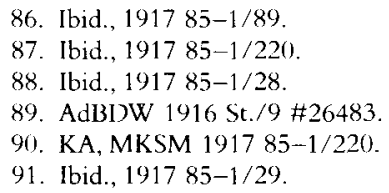


Women similarly benefited from the belief that their duty to love and nurture male family members took precedence over other competing duties, such as the duty to protect state interests. Competing loyalties to family and state came to the fore in cases of women charged with aiding and abetting deserters. Desertion became an increasingly serious problem for the Habsburg military as the war progressed. While scholars have focused on desertion of soldiers from non-German-speaking regions, deserters also came from, and sought refuge in, the capital city. ${ }^{92}$ Despite the threat that desertion posed to military operations, it appears that Habsburg authorities did not encourage women to report husbands or close family members who had deserted. On the one hand, according to Austrian law one could not offer shelter to or otherwise protect a deserter. According to the penal code, it was illegal,

to offer a helping hand of any kind to a serviceman who has fled from the military (fugitive, deserter) by providing directions, by clothing, hiding, or offering shelter, and thereby promoting his flight or hampering the investigation and capture of the fugitive. ${ }^{43}$

On the other hand, a 1917 note from the military chancellery specified that petitions for leniency in desertion cases involving women were not necessarily to be judged by "the letter of the law" but also by "humane" considerations. "All efforts are being made ... to free the wife and close relatives of the legal obligation to report husbands and relatives." ${ }^{, 94}$ Officials wanted to catch deserters, but not at the cost of breaking family ties. Thus, when Marie Hotton, a twenty-five year-old feather arranger in Vienna, offered shelter to her fiancé (and later husband), a deserted infantrist, over six months in 1916, offering him "a helping hand" and hindering inquiries into his whereabouts, she was sentenced to four months in jail. Her sentence was reduced on the grounds that she didn't possess "reprehensible Gesinnung" but rather had broken the law "only out of love" for her man. ${ }^{45}$ In other cases motherly love and sisterly love were cited as grounds for women's reduced sentences. Maria Slanina, a mother whose nineteen-year-old son, Ludwig, had deserted and hidden his uniform in her Vienna apartment, reported helplessly, "As a mother it would have been very difficult for me to turn him in. I would have probably even let him stay overnight at my place longer." She fed him periodically before he was picked up by the military police. ${ }^{96}$ Deserters sought from their female family members

92. On desertion, see Richard Plaschka, et al., eds., Innere Front: Militärassistenz, Widerstand und Umsturz in der Donaumonarchie 1918, 2 vols. (Munich, 1974). In 1917, the Ministry of the Interior ordered the Statthalterei in Vienna to compile monthly reports about "staatspolizeilich relevante Vorfalle." Aiding a deserter appears frequently in these reports. NÖLA Präs. "P" 1917 VII, 752.

93. $\$ 220$ Austrian penal code. Penalty was a fine and six months to a year in prison.

94. Note relating to case of Sofie Novozamski. KA, MKSM 1917 85-1/237.

95. Ibid., 85-1/110.

96. Wiener Stadt- und Landesarchiv, Landesgericht Strafsachen 1917 Fasz. 514 Zl. 8922, document 21. 
food, clothing, nurturance, and a home, just those things that state authorities felt women were by nature endowed to provide. These soldiers had broken the law and needed to be apprehended; but for a woman to turn in her husband, son, or brother was to break a bond even more sacred, and more important for society in the long run, than military discipline.

In a political atmosphere characterized by anonymous grumbling, intrigue, desertion, and myriad other dangers to the state, authorities were forced to articulate the standards of legal accountability set for the citizenry. These cases of wartime leniency for women demonstrate that accountability was not genderneutral; authorities highly valued women precisely for their womanly and motherly service to Austria.

\section{The Women's Auxiliary Labor Force}

Commonly held assumptions about the appropriate venue for women's state service would be challenged by Austria-Hungary's staggering wartime losses. By the end of 1917, 780,000 men had been killed and another 1,600,000 had been taken prisoner. ${ }^{97}$ These losses prompted the state to recruit women for positions that would take them beyond the home front and for which they were not naturally suited. In 1917, the Army High Command, looking to replenish the depleted ranks of its soldiers, announced an ambitious program to free up for front service the "greatest possible number of troops" by replacing men in army support positions with women. ${ }^{98}$ It established the Women's Auxiliary Labor Force in the Field (weibliche Hilfskraffte im Felde), which came to employ between 36,000 and 50,000 women in 1917 and 1918. As the historiography on World War I has shown, women in many European countries performed tasks in wartime that had formerly been designated as male. The Women's Auxiliary Labor Force merits special attention because it had women serving Austria in ways that so closely resembled military service. Unlike the nurses of the Austrian Red Cross, who had been working under army contract since 1915, and who were publicly celebrated for the specifically feminine virtues of their service, the volunteers of the Women's Auxiliary Labor Force met with official resistance and public derision. ${ }^{99}$ As army employees working in regions not actually at the battle front, but behind the lines in support areas, they served as laboratory assistants, clerical workers, technicians, and telephone and telegraph operators. They wore uniforms; they referred to themselves as "enlisted"; they were relatively well paid; they traveled far from home and worked alongside

97. Plaschka, et al., Innere Front, 1:44.

98. KM memo, 3 January 1917. KA, AOK GZNB 1917 carton 3750 \#605.

99. Next to the image of the virtuous "angel-like" nurse, was a counter image of the nurse as whore. See Ernst Hanisch, "Die Männlichkeit des Kriegers: Das österreichische Militärstrafrecht im Ersten Weltkrieg," in Geschichte und Recht, ed. Angerer et al., 329-30. 
men. The public controversy the program generated, and great resistance to it from within the army itself (despite urgent promotion by the High Command) suggest that the definition of "Austria's women" was under great strain by war's end. In the interest of the Austrian war effort, women filled these positions, yet commentators felt the feminine virtues of those who enlisted were jeopardized in the process.

It was paradoxical that volunteers of the Women's Auxiliary Labor Force were perceived by the public as independent adventure-seekers, because they actually gained access to the program through the deeds of male family members. A war ministry recruiting memo emphasized, "Of the applicants, first priority is given to widows and orphans of active military persons," followed by widows and orphans from previous wars. ${ }^{1(1)}$ Although we saw above that citizenship was not a status women possessed independently, the army sought women between the ages of 18 and 40 who were citizens of Austria, Hungary or Bosnia-Herzegovina, and who demonstrated strong moral character and political reliability. The latter were certified by a statement of good character from authorities in the woman's hometown. The Army High Command recruited women for service through the press, posters, employment offices, and through direct appeal to women's organizations. Authorities stressed the provisional nature of the assignments, and attempted to quell fears that the service might damage what was most womanly in a woman-her childbearing potential. "Only older women" were to be stationed in areas with poor hygiene."'1

The threats that service in the Auxiliary Labor Force posed to a woman's nature were numerous. First, did she remain a woman at all? Close reading of army documents on the subject shows that male administrators of the program rarely, if ever, referred to the volunteers as women. Rather, they referred to them in the plural as female auxiliary laborers (weibliche Hilfskräfte), which was shortened to "w. Hk." This abbreviation subtly erased (on paper, at least) the unsettling fact that women were being sent into the field. Second, the army was loathe to admit that the volunteers wore uniforms, stating emphatically that the "form of dress is in no way intended as a uniforming of the female auxiliary laborers. The aim is rather to simplify the production of garments and to curtail special wishes and demands." 112 Yet sketches and photos of the women's garments show them to be uniforms (see figure1). Finally, authorities worried that the experience of serving in the auxiliary force would spoil women's futures as homemakers. Reports that volunteers had not been keeping their quarters clean prompted fears that women who would return to "normal bürgerliche circum-

100. KM memo, 3 January 1917. KA, AOK GZNB 1917 Carton 3750, \#4605.

101. Ibid.

102. Bestimmungen für die Aufnahme weiblicher Hilfskräfte und deren Verwendung im Bereiche der A.i.F, emphasis in original. KA, MS/ I. Weltkrieg Allg. 111, fol. 1-241. 

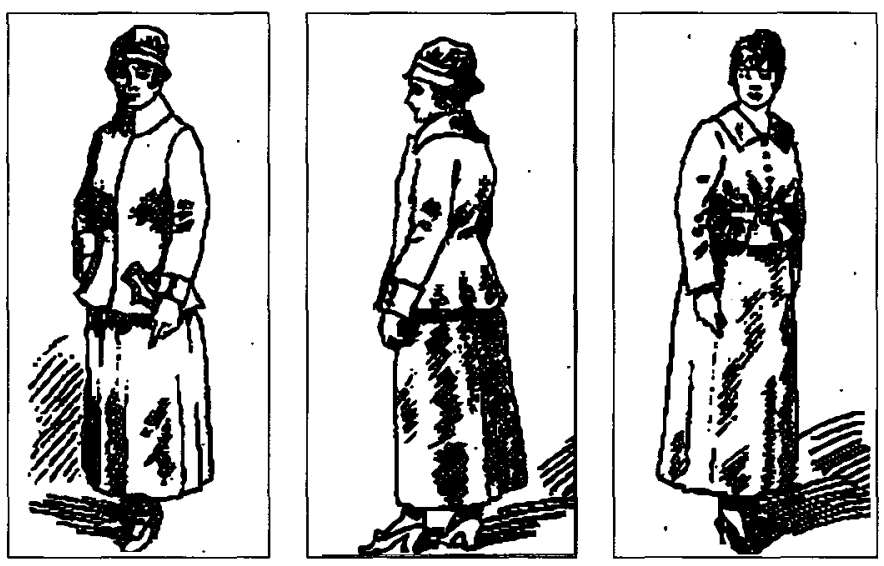

Figure 1. Uniforms for the Women's Auxiliary Corps.

stances" at war's end had lost the feminine touch. Measures were taken to ensure that the women, who lived in sex-segregated military housing did not "lose the look and feel for a cozy home" while they were in the field."103

Many contemporaries expressed disdain for the Women's Auxiliary Labor Force. As the Army High Command had made explicit, employing the women freed up men who had heretofore been exempted from service. This "exchange" made the women highly unpopular among home front men and their families. In addition, some in Vienna resented the relatively high pay for women in the most technical positions. Laboratory assistants, Hughes telegraph operators, and some office workers earned between 120 and 200 crowns per month, although most earned far less. ${ }^{104}$ The Illustriertes Wiener Extrablatt painted a luxurious picture of volunteer life, noting to its readers that in addition to high pay, the women enjoyed free room and board, travel to and from their assignments, and a yearly clothing allowance. ${ }^{105}$ The same criticism was never leveled at soldiers who received the same benefits for their military service. Other complaints came from within the army itself, from men who understandably felt threatened by the arrival of the female workers. Stationed comfortably behind the lines in office or support positions with the designation "indispensable," these men were suddenly rendered dispensable by a program

103. Nachrichtenblatt ..., ibid.

104. Bestimmungen... Volunteers performing more traditionally "female" work-as mess cooks for officers and soldiers, seamstresses, waitresses, launderers and cleaners-earned considerably less, between 40 and $90 \mathrm{~K}$ monthly, in ibid.

105. Mllus. Wiener Extrablatt, 24 April 1918. 
whose stated aim was an "increase in troops." 106 They accused the newcomers of being unqualified, frivolous adventure-seekers. The Reichspost printed the comments of a man who had allegedly seen one of the women "at work" in a military office. The former waitress

proudly assured me that after "completion" of a sixteen-hour (!) course [she] now had complete command of typing, stenography, accounting, and military business protocol. The young lady was in our office one month. During this time she read (in secret, of course) all the novels she could get her hands on, naturally during working hours.

He added that on her first day of service the volunteer requested to leave work early "because she had to go to the cinema." 107

The high pay and the seemingly glamorous lives of the volunteers fed rumors that the women were prostitutes. An anonymous letter-writer speaking on behalf of "the little people" implored Kaiser Karl to intervene in the scandalous arrangement whereby officers mingled with the "thirty thousand womenfolk who aren't qualified for the work" and who were sent merely to service the whoring men [Hurenkerle]. "The state pays these women to service the filthy officers." 108 Army authorities worried that contact with the female volunteers had damaged the reputation of the army. "The unhindered trafficking of officers with female auxiliary laborers in the streets and in public places (cinema, front theaters, and coffee houses)" spawned rumors that made their way back to the home front. "This damages most acutely the impeccable reputation of our officer corps and seriously discredits the program of female recruitment, which is necessary ... for saving on men." ${ }^{109}$ Individual volunteers complained that their honor had been insulted by the sexual innuendo that attached itself to women in service. Olga Fil, a telephone operator with the foreign ministry, was apprehended at a train station by a detective who "suspected me to be a lady of quite another profession." A local inspector defended the action, noting that "the monitoring of female persons is quite rigorous, but complies with the wish of the responsible army commanders that women traveling aimlessly in the vicinity of the war zone be kept as far away as possible." "The repeated declarations of the high command that the Women's Auxiliary Labor Force was essential to the Austrian war effort because it freed up troops at a time of manpower shortage could not dispel widely-held suspicions that women's service in the field was of a frivolous or sexual rather than patriotic or professional nature.

106. Bestimmungen ... KA, MS/I. Weltkrieg Allg. 111, fol. 1-241.

107. WSLB ZAS Frauenarbeit III, Reichspost, 10 October 1918 (Abend).

108. Anonymous letter to Kaiser Karl, May 1918. AdBDW 1918 St./16 \#55053.

109. Memo from k.u.k. 11 Armeekommando, 24 August 1918. KA MS/ I. Weltkrieg Allg. 111, fol. 1-241.

110. Letter of Olga Fil and official response, 23 July 1917. AdBDW 1917 St./2 \#48164. 
To begin to assess how the women themselves conceived of their service we can look to Maria Mosconi and Countess Marie Anna Rumerskirch, two women who served in the field and left written record of their experiences. In both cases, Austria figures prominently in the women's accounts of their motivations. Mosconi, the Italian translator who was fired from her job and confined in Vienna as a political unreliable expressed desire to serve Austria as her father had in battle. Accused of being a loose-lipped gossip who fraternized with enemy civilians, Mosconi fit the stereotype of a woman who couldn't keep secrets. It was precisely this inability to keep secrets that prompted some army officials to doubt women's capabilities to serve the state in a time of peril. Volunteers in the Women's Auxiliary Labor Force were required to sign an oath to protect state secrets, but male counterparts doubted their trustworthiness. "Especially confidential documents may not be processed by the female auxiliary laborers," a War Ministry memo noted. ${ }^{111}$ Mosconi's real or perceived inability to recognize the gravity of state secrets - a feminine weakness that echoed nineteenth century justifications for the exclusion of women from politics - ultimately disqualified her from serving Austria.

Similar feminine political naiveté-this time an inability to distinguish between enemy and ally - was ascribed to Countess Marie Anna Rumerskirch, a hospital volunteer serving near the Russian front. She was fired from her position after rumors, allegedly started by her maid servant, circulated to military authorities. Rumerskirch was accused of making herself unpopular at the hospital by caring exclusively for Russian officers and talking to them on the street. From her temporary residence at Vienna's Grand Hotel she launched an ambitious letter campaign to clear her name. She asked the kaiser to intervene on her behalf, stating that her only aim was "to perform patriotic work in wartime." The malicious rumors could not dampen her patriotic Gesinnung which compelled her to serve near the front "where help is most needed." 112 The other letters in Rumerskirch's military file convey her sense of honor at serving her country, and her wounded pride at being banned from sensitive territories near the front. Her articulations of Austrianness, established in her mind through Kriegsdienst, clashed with contemporary gendered notions of whether (and in what capacity) women were temperamentally suited to serve the state. She was never directly charged with spying, but her reputation was stained by a vaguely defined "suspicion of espionage" stemming from her alleged flirtations with the enemy.

Of all Austria's women, the volunteers came closest to serving the state in ways that resembled men's service. But clearly, something about the "w. Hk." was deeply troubling to contemporaries. They were accused of a laundry list of 
feminine violations. They didn't display selflessness (adventure seeking); they were immoral (prostitutes posing as office workers); they were frivolous (novels and cinema); they did not dress like women (uniforms); and they neglected key feminine duties (poor housekeeping). Although we know that family connections were important in the selection process, the women were not performing their work in a recognizable family capacity as mothers, sisters, or daughters. They not only worked outside the home, they left the home front altogether and moved into areas where, in the cultural imagination, men waged war. Vehement opposition to the program suggests that Austrian society in 1917 and 1918 was not ready for women's service that extended beyond traditional, familial roles.

In November 1914, twenty-four year-old store clerk Josephine Cieslak was arrested in Vienna for making antistate comments. An Austrian citizen (by law) suspected of spying for Russia in a city closer to the front, she had been relocated to Vienna for confinement. While in the capital, she struck up a conversation in a café with soldiers on leave, who later reported to police that Cieslak despised Austria so much that she "began to shake in agitation when the word 'Austria' was spoken aloud." 113 This incident, coming just a few months after the optimistic founding of the Frauenhilfsaktion Wien, suggests that the project of mobilizing "Austria's women" faced challenges from the very beginning. While some organized women's groups seem to have found a mission in war, "realizing" a latent Austrianness and expressing it through volunteer works, individual women in the venues of everyday life practiced very different sorts of politics. They committed, or were suspected of committing, acts of violence, incivility, betrayal, or disloyalty that did not conform to contemporary notions of women's special nature. The state nonetheless incorporated feminine virtues of maternalism, love, and selflessness in its legal and administrative decisions about women's citizenship.

This assessment of women's attitudes and actions during wartime contributes a number of things to our understanding of late imperial Austria. First, it allows for a shift away from the traditional practice of writing World War I Austrian history in the form of an obituary. The early proclamations of the Frauenhilfsaktion Wien read more like birth announcements: they tell of the political arrival of a new cadre of incipient citizens eager to serve the state. While the state may have been in a process of decline- "decline and fall" being the leitmotif for historiography on the period - women themselves were in a process of 
becoming citizens. Their legal and economic interactions with the state accelerated markedly during wartime. In each of these interactions-whether involving marriage laws, financial subsidies, legal accountability, or state employment-definitions were at stake. Authorities and women had to hammer out matters on which positions had not previously been articulated. World War I forced a working definition of female citizenship. Second, if indeed the state was in decline during these years, nameless womenfolk must be given credit for publicizing the state's inability to provide food and other resources in return for civilian sacrifice. We know from the copious attentions that Viennese law enforcement and Habsburg ministerial agencies devoted to female public protest that contemporaries regarded such actions matters of state. Historians who have written of late imperial politics without considering Austria's women have overlooked important questions about state legitimacy that women raised in informal political venues. Finally, we can conclude that the crisis of the Austrian Staatsidee was accompanied in its final years by a simultaneous crisis of an Austrian Frauenidee - an idea that women could be expected to behave a certain way publicly and politically due to a distinctly feminine nature. This assumption, by no means a new idea in the early twentieth century, was disproved during World War I, and yet it was one of the legacies passed from Imperial Austria to the postwar successor states.

OREGON STATE UNIVERSITY 